\title{
The Estimation Loss and Gain of Mammal Species Diversity due to Oil Palm Plantations: A Case Study of BPME Estate, Riau, Indonesia
}

\author{
Satrio Suryadi Nugroho*, Yanto Santosa \\ Ecology and Wildlife Management Division, Forest Resource Conservation and Ecotourism \\ Department, Faculty of Forestry, Bogor Agricultural University, Bogor, Indonesia
}

\begin{abstract}
The existence of palm oil plantation development allegedly resulted in a ecological losses, including the sustainability of mammalian diversity. So far the ecological losses to the diversity of wildlife species, especially mammals, have not been widely known. Therefore, in February 2018 a direct observation was conducted at 5 observation paths with Strip Transect Method and simultaneous data retrieval, three repetitions at 8.0010.00 a.m. and $16.00-18.00$ p.m. In addition, there are 10 Rodentia traps and 15 camera traps on each observation path. The analysis results obtained the total number of species and wealth of the highest species on oil palm plantation cover. The highest similarity index was obtained from youngaged oil palm (IS $=0.67$ ) and the lowest commonality index was in old-aged oil palm (IS $=0.50$ ). On the other hand, the old-aged oil palm has the highest value of mammal diversity and the lowest loss value, while the young-aged oil palm has the lowest mammal diversity value. Overall, land cover changes to oil palm plantations have a positive impact due to the addition of two species of mammals and the value of species diversity did not change significantly.
\end{abstract}

\section{Introduction}

Indonesia is known as a country with a wealth of very high biodiversity, both in ecosystem scale, species and genetics to attract the attention and admiration of people around the world [1];[2];[3]. However, Indonesia is also noted as a country that has a remarkable vulnerability to the decline/loss of potential biodiversity loss. Among the many factors causing biodiversity loss, the development of oil palm plantations (which makes Indonesia the world's largest palm producer) is considered to be one of the determinants [4];[5];[6]. The Indonesian state also has over $80 \%$ of the remaining primary forests in Southeast Asia, where many endemic species are threatened with extinction by some of the increasing levels of global deforestation [7];[8];[9];[10]

Biodiversity has been recognized globally, as one of the determinants of the sustainability of an ecosystem [11]. When the expansion of oil palm plantations is accused of threatening wildlife such as Orangutans, Sumatran Tigers, and Rhinoceros (biodiversity loss), a more in-

* Correspondent Author: satriosuryadinugroho@gmail.com 
depth study of the issue of biodiversity loss is needed, as research results also show that oil palm plantations provide habitat for another biodiversity (biodiversity gains). Changes in land cover (forests and shrubs) due to human activities and development to oil palm plantations will also impact on the changing conditions and potential for biodiversity. The change can take the form of loss or even loss of potential biodiversity (biodiversity loss) that was present or easy to find. However, it may be the opposite, that is, due to changes in land cover that initially in the form of land (open land cover) which is considered not enough to have the potential of biodiversity (plant and wildlife) into oil palm plantation, it is believed to be beneficial for the development of some wildlife especially predatory animals such as owls and python [12].

Thus, the potential impacts of oil palm expansion on tropical forests and biodiversity are the major conservation concerns of the world [13];[14]. It also raises concerns over oil palm plantations due to rapid and widespread agricultural expansion, posing a serious threat to natural ecosystems around the world [15] including mammalian diversity. Mammals play a role in pest control, seed dispersers, predators, and pollinators for plants [16];[17];[18]. The existence of mammals plays an important role in the balance of natural ecosystems. In addition, mammals also have several ecological functions, namely a soil fertilizer, flower pollinator, seed dispenser, an organic fertilizer producer, biological pest control, helping the process of recycling minerals from plants, indicating the destruction of forest habitat and indicators of air pollution by heavy metals [19]. Therefore, it is necessary to conduct research to find out the diversity of mammal species in various land cover in oil palm plantation, as it is still relatively little research on this matter.

\section{Experimental details}

\subsection{Time and location}

The research was conducted at BPME Estate, Riau Province in February-March 2018.

\subsection{Data collection}

Materials and equipment used in this research include stationery, tally sheet, drone DJI Mavic, rodentia trap, binocular, regional map, GPS, digital camera, camera trap, timer and mammal observation manual. The object of the study was the type of mammals and the number of individuals found in each habitat. The data taken are primary and secondary data. Primary data include mammal species in each habitat, number of individuals, time, the location of direct encounter and indirect encounter data (sound, footprint, and feces). The study used a 1-km strip transect method with right and left widths of $50 \mathrm{~m}$ each. Considering the impact is the difference between the condition of species diversity before being turned into oil palm plantation with the condition of oil palm plantation, this research is conducted on five land cover. Based on the results of literature searches, interviews of BPME Estate managers and communities around the palm plantation, as well as the analysis results of landscaping interpretation 2 years before the palm oil plantation, was built, the type of land cover in the area is dominated by shrubs and coconut plantation. Therefore, observation on the area before the oil palm plantation (accumulation between shrubs and coconut plantation), while the observation path as a comparison of palm oil plantation, observation is done in the area of young-aged oil palm, middle-aged palm plantation and old-aged palm plantation. In addition, there are also 10 rodentia traps and 15 camera traps on each observation path. Trap bait used is a mixture of shrimp paste and peanut butter. Observations were made in the 
morning (06.00-08.00 a.m.) and evening (04.00-06.00 p.m.) as three repetitions on each path in each land cover.

\subsection{Data analysis}

\subsubsection{To estimate the impact of species diversity as a result of oil palm plantations, it is used to calculate the diversity index and species richness as follows:}

\subsubsection{Diversity Index $\left(\mathrm{H}^{\prime}\right)$}

The species diversity in each land cover type uses the Shannon-Wiener Diversity Index (Magurran 1988), by the formula:

$$
\mathrm{H}^{\prime}=-\sum P i \cdot \ln (P i)=-\sum\left(\frac{n i}{N}\right) \cdot \ln \left(\frac{n i}{N}\right)
$$

Information :

$\mathrm{H}^{\prime} \quad$ : Index of diversity

$\mathrm{Ni} \quad$ : Number of individual types i

$\mathrm{N} \quad$ : Number of individuals of all types

\subsubsection{Species Richness Index (Margalef Index)}

The species richness index serves to determine the species richness of each species within each community encountered. The following formula is used [20]:

$$
\mathrm{D}_{\mathrm{mg}}=(\mathrm{S}-1) / \ln (\mathrm{N})
$$

Information:

Dmg : Index of type riches

$\mathrm{S} \quad$ : Number of types

$\mathrm{N} \quad$ : Total number of individuals across species

\subsubsection{To estimate the impact of species composition as a result of oil palm} plantations, the Sorensen Type Similarity Index [20] is used:

$$
\text { IS }=\frac{2 c}{a+b}
$$

Information:

a: Number of species found in community A

b: Number of species found in community $B$

c: Number of species found in communities A and B

\section{Result and discussion}

\subsection{The Impact of oil palm plantations on the diversity of mammals}

Based on observations on the five land cover types in BPME Estate, it was found 30 individuals from 6 species consisting of five families: Sciuridae (1), Muridae (2), Suidae (1), Viverridae (1), and Felidae (1). Based on observations on five predetermined paths, the data 
of species number, diversity index and index of species richness on each land cover (Table 1). The data show that the type of land cover that has the highest number of species is found in land cover prior to oil palm plantations (accumulation between shrubs with coconut plantation) and old-aged oil palm as many as four (4) types. A high number of species in both locations also caused the two sites to have the lowest grade index value compared to another land cover. Meanwhile, the encounter of the lowest mammal species $(S=2)$, is in the cover of young-aged oil palm plantation followed by the value of the species diversity index $\left(\mathrm{H}^{\prime}\right)$ which decreased to 0.69 .

Table 1. The types and distribution of mammals encountered in oil palm plantations BPME Estate

\begin{tabular}{|c|c|c|c|c|c|c|c|}
\hline \multirow{3}{*}{$\begin{array}{c}\text { No } \\
\text {. }\end{array}$} & \multirow[t]{3}{*}{ Species Name } & \multirow[t]{3}{*}{ Scientific Name } & \multirow[t]{3}{*}{ Family } & \multicolumn{4}{|c|}{ Observation Areas } \\
\hline & & & & \multirow{2}{*}{$\begin{array}{l}\text { Before Oil } \\
\text { Palm } \\
\text { Plantation }\end{array}$} & \multicolumn{3}{|c|}{$\begin{array}{c}\text { Oil Palm Plantation } \\
\text { (OPP) }\end{array}$} \\
\hline & & & & & $\begin{array}{c}\text { YO } \\
\text { P }\end{array}$ & $\begin{array}{c}\text { MO } \\
\text { P }\end{array}$ & $\begin{array}{c}\mathrm{OO} \\
\mathrm{P}\end{array}$ \\
\hline 1 & $\begin{array}{l}\text { Plantain } \\
\text { Squirrel }\end{array}$ & $\begin{array}{l}\text { Callosciurus } \\
\text { notatus }\end{array}$ & Sciuridae & 4 & 0 & 2 & 10 \\
\hline 2 & $\begin{array}{l}\text { Malayan Field } \\
\text { Rat }\end{array}$ & Rattus tiomanicus & Muridae & 0 & 0 & 1 & 1 \\
\hline 3 & $\begin{array}{l}\text { Giant Sunda } \\
\text { Rat }\end{array}$ & Sundamys muelleri & Muridae & 1 & 0 & 0 & 0 \\
\hline 4 & $\begin{array}{l}\text { Eurasian Wild } \\
\text { Pig }\end{array}$ & Sus scrofa & Suidae & 5 & 1 & 1 & 0 \\
\hline 5 & $\begin{array}{l}\text { Common } \\
\text { Palm Civet }\end{array}$ & $\begin{array}{l}\text { Paradoxurus } \\
\text { hermaphroditus }\end{array}$ & $\begin{array}{c}\text { Viverrida } \\
\mathrm{e}\end{array}$ & 0 & 0 & 0 & 1 \\
\hline 6 & Leopard Cat & $\begin{array}{l}\text { Prionailurus } \\
\text { bengalensis }\end{array}$ & Felidae & 1 & 1 & 0 & 1 \\
\hline \multicolumn{4}{|c|}{ S } & 4 & 2 & 3 & 4 \\
\hline \multicolumn{4}{|c|}{$\mathrm{H}^{\prime}$} & 1.16 & 0.69 & 1.04 & 0.79 \\
\hline \multicolumn{4}{|c|}{ Dmg } & 1.25 & 1.44 & 1.44 & 1.17 \\
\hline
\end{tabular}

Information: YOP (Young-aged Oil Palm); MOP (Middle-aged Oil Palm); OOP (Old-aged Oil Palm)

The high number of species on the land cover before oil palm and old-aged oil palm has a positive impact because both sites have the highest number of species $(S=4)$, so if it is assumed that shrub and coconut plantation changes into oil palm plantations do not provide significant change, where the value can be seen in Table 2.

Table 2. Impact of oil palm plantations on the diversity of mammals in each land cover

\begin{tabular}{|l|c|c|c|}
\hline & $\begin{array}{c}\text { Young-aged Oil } \\
\text { Palm }\end{array}$ & $\begin{array}{c}\text { Middle-aged Oil } \\
\text { Palm }\end{array}$ & Old-aged Oil Palm \\
\hline $\begin{array}{l}\text { Impact on Number of } \\
\text { Types }\end{array}$ & -2 & -1 & 0 \\
\hline Impact on H' & -0.47 & -0.12 & -0.37 \\
\hline Impact on Dmg & +0.19 & +0.19 & -0.80 \\
\hline
\end{tabular}

Information: (-) decreased, (+) increased 


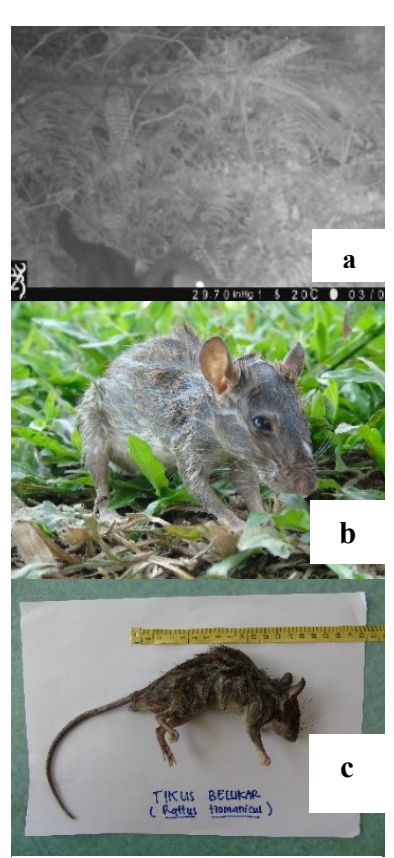

Fig. 1. a Paradoxurus herma-phroditus b Sundamys muelleri c Rattus tiomanicus
Oil palm plantations impacted a decline of species in youngaged oil palm and middle-aged oil palm, where the largest differences is in the young-aged oil palm and the smallest difference in the middle-aged oil palm. Both sites show less number of species compared to land cover prior to oil palm. In contrast, the difference between the index of species richness in both sites increased by 0.19 . On the difference of index of species diversity showed different things again, in both locations also have decreased value of the index of species diversity and also proportional to the decrease in the number of types. Meanwhile, in the old-aged oil palm also decreased the value of the diversity index, but not directly proportional to the number of species due to the different number of species and the number of individuals at each location. This is supported by [21], which states that the value of species diversity is not only determined by the number of species but also determined by the number of individuals of each species. When examined again, young-aged oil palm and middle-aged oil palm land cover have been decreasing the number of species due to several factors. One of the factors that can affect species diversity in a habitat is the level of disturbance from humans [22]. In palm oil plantation areas, the level of human activity is quite high as there are palm fruit harvesting and spraying activities to remove pests and weeds. Based on interviews to the manager, the average spraying is done once every three months and the harvesting of the oil palm fruit is done every two weeks, so that with many human activities also affect the diversity of species in a habitat.

Overall, the comparative impacts of oil palm plantation cover (accumulation of youngaged oil palm, medium-aged oil palm, and old-aged oil palm) with shrubs and coconut plantation do not make a significant difference, but instead provide new species such as Common Palm Civet (Paradoxurus hermaphrodites) and Malayan Field Rat (Rattus tiomanicus), but has also eliminated the Giant Sunda Rat (Sundamys muelleri) species that are not found throughout the palm oil plantation observation path, as can be seen in Figures 1 and 2.

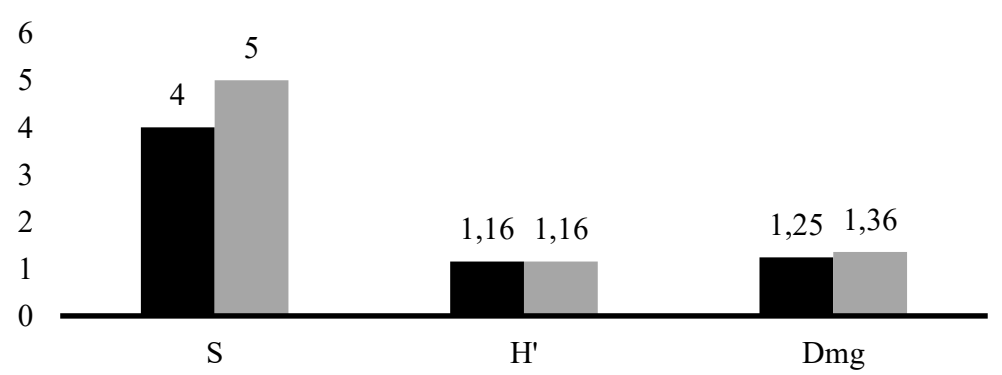

Fig. 2. Impact of oil palm plantations on the diversity of mammals

After merging all the paths on the oil palm plantation cover, there was an increase in the diversity of mammals. Described in Figure 2, the land cover after palm has a higher number of species and higher grade index values. Furthermore, there is no change in the index of 
species diversity, so in that case, it shows that the change of shrubs and coconut plantation into oil palm plantation area did not give significant change. The difference in value in each location and the high number of species is also influenced by the size of the habitat [23], where this research on oil palm plantation cover has a larger area than the area before being made oil palm plantation. Furthermore, the high number of species, the index of species diversity and the index of species richness is influenced by the variation of the level of vegetation diversity. In land cover prior to oil palm plantations (shrubs) generally vegetation only in the form of seedlings and saplings that resulted in the absence of mammals due to a limited source of feed. The results of this study are consistent [24] hypothesis which suggests that an increase in the number of different habitats may lead to an increase in species diversity. In addition, the high index of mammal diversity is related to the high diversity of vegetation types in oil palm plantations [25].

\subsection{The Impact of Oil Palm Plantations on Mammal Number of Species}

Comparison of the Sorensen Similarity Index from shrubs and coconut plantation with all types of land cover lines in oil palm plantations (accumulation of young-aged oil palm, medium-aged oil palm, and old-aged oil palm) shows that the value at each location ranges from 0.50 to 0.67 indicating the similarity between cover palm oil plantations that tend to be different (Figure 3).

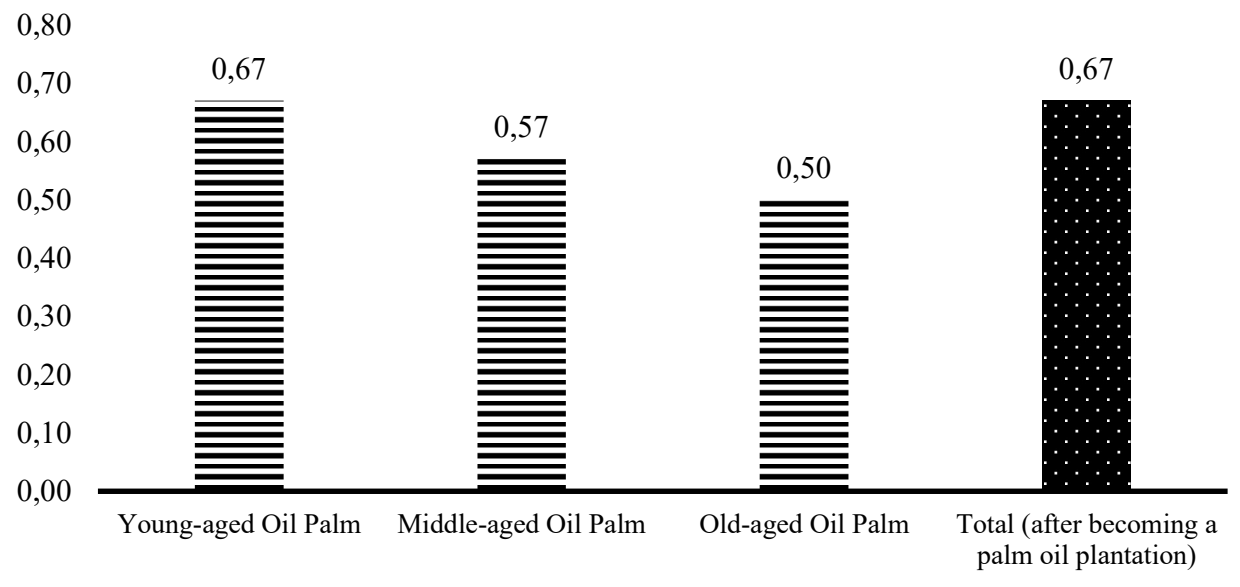

Fig. 3. Comparison of the Sorensen type similarity index between land cover before being used as an oil palm plantation area after being converted to oil palm plantation

The species similarity index between shrubs and coconut plantation with the young-aged oil palm has the highest value (IS $=0.67$ ), the high value is due to the same number of species between the two locations and the distance between sites is close together, causing high IS value. The species similarity index between shrubs and coconut plantation with middle-aged oil palm has a smaller value than the previous value (IS $=0.57$ ), the value is obtained because the same number of species between two locations there are two types, as well as the distance between locations, is quite far apart. Furthermore, the similarity type index between shrubs and coconut plantation with the old-aged oil palm has the lowest value (IS $=0.50$ ), the value is due to the same number of species between the two locations and the distance between the locations is far from each other, thus causing low IS value. Meanwhile, if the value of the similarity index of the species is calculated as a whole, land cover before oil palm plantation with oil palm plantation area shows a high enough value is also equal to 0.67 with the same mammal species in both locations as much as three (3). The change of shrub and coconut 
plantation into oil palm plantations have affected the similarity index of species, but based on research there is still the same type between the two locations. This indicates that there is still a common characteristic of composition between shrubs and coconut plantation with oil palm plantations. The composition of the two communities said to have a similar degree of composition if it has a species equality index value $>0.50$ [26]. Two similar communities are generally no more than $2 / 3$ of the same species can be found. The IS scores that range from 0.25 to 0.50 already show the great species similarity [27]. A value above 0.50 indicates that both locations are the same community, while a value less than 0.25 indicates that the community is different.

There is an increase in the type of mammal species of Malayan Field Rat (Rattus tiomanicus) and Common Palm Civet (Paradoxurus hermaphroditus) due to changes to palm oil plantations. However, in detail, the loss or addition of mammals to each type of land cover can be seen in Figure 4.

$$
\text { Percentage of Loss (\%) : } \quad \text { Percentage of Gain (\%) }
$$

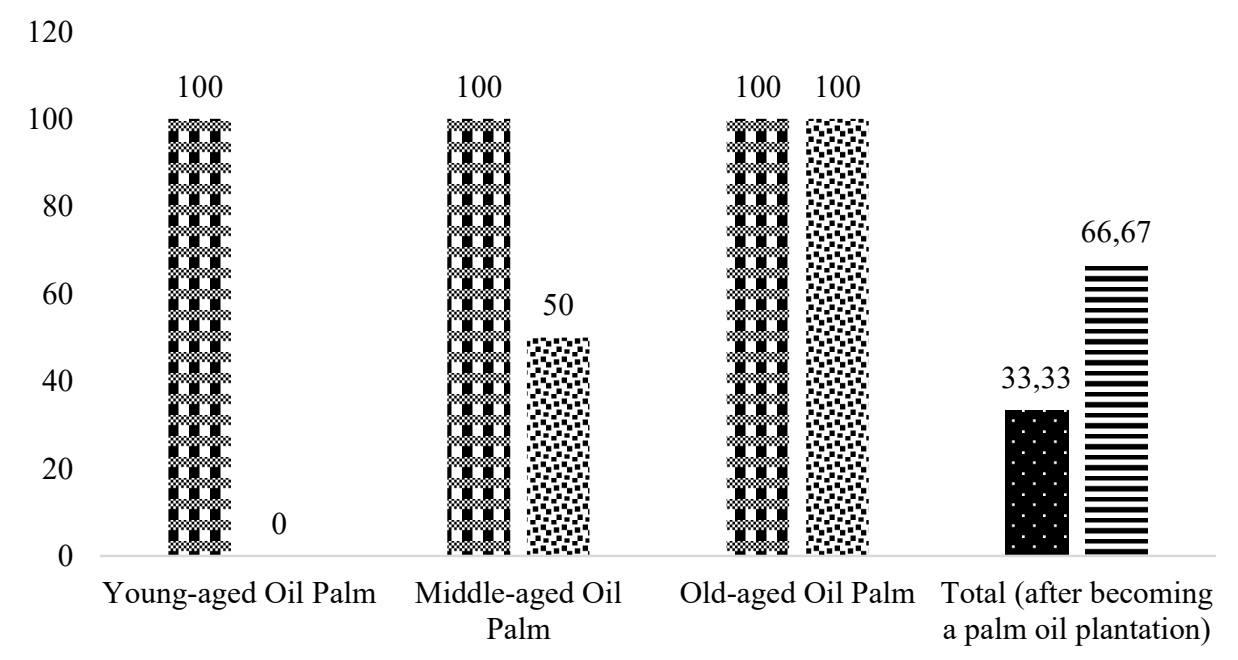

Fig. 4. Comparison of percentage loss and acquisition of mammal species on each land cover

Figure 4 explains that shrub and coconut plantation changes into oil palm plantations (accumulation of young-aged oil palm, medium-aged oil palm, and old-aged oil palm) have eliminated certain types of mammals. The number of mammals which lost on land cover change before oil palm plantations become a young-aged oil palm, resulted in decreasing the index of species diversity to $H^{\prime}=0.69$ and increasing the species wealth index by Dmg = 1.44. The occurrence of changes in the index value has resulted in the loss of species amounting to two (2) types or as many as $100 \%$ of mammals such as Plantain Squirrel, Malayan Field Rat, and Giant sunda Rat are not found in the young palm area (Figure 4). The absence of the Rodentia order is due to the limited source of feed in the young-aged oil palm, such as the unproductive fruit of oil palm due to the young-aged oil palm (Table 3 ). The order of Rodentia like the type of squirrel is commonly found eating the raw palm fruit in oil palm plantations [28]. As a result of the loss of Rodentia, order animals can increase the activity of herbivores such as insects. The type of order Rodentia possesses as a detrivore, insectivore and granivore [29].

Changes in shrubs and coconut plantation to middle-aged oil palm are causing declining index of species diversity to $\mathrm{H}^{\prime}=1.04$ and increasing the species richness index by Dmg $=$ 
1.44. As a result of the change in the index value, it has resulted in the loss of species of Leopard Cat and Giant Sunda Rat with 100\% percentage, but from the change also on the new species change that is Malayan Field Rat with 50\% (Figure 4). Loss of Leopard Cat may affect the balance of ecosystems as they can increase Rodentia order animals such as rats and squirrels that often feed on palm fruits and are considered pests (Table 3). Carnivorous species (Javan Mangoose, The Javan ferret-badger, The Sunda stink badger, Common Palm Civet and Leopard Cat) have a role as a balancing ecosystem mainly as a predator of small animals such as rats and squirrels [30]. This small carnivore can be relied upon as a key species capable of preventing the explosion of rat populations and other small vertebrate animals. The presence of a new species (Malayan Field Rat) has provided the benefits of lowering herbivore [29]

Furthermore, changes in shrubs and coconut plantation to old-aged oil palm have resulted in decreasing of species diversity index to $\mathrm{H}^{\prime}=0.79$ and decreasing index of species richness by $\mathrm{Dmg}=1.17$. As a result of the change in the index value, causing the loss of two species of Giant Sunda Rat and Eurasian Wild Pig with percentage 100\%. However, from the change also the change of new species namely Common Palm Civet and Malayan Field Rat with the same percentage that is equal to $100 \%$ (Figure 3). The absence of Eurasian Wild Pig in the old palm, Eurasian Wild Pig and Leopard Cat only found in oil palm plantations and not found in the forest [31]. The situation is presumably due to the location of adjacent oil palm directly with the coconut plantation, so that Eurasian Wild Pig can move easily from oil palm plantation to coconut plantation and vice versa. The presence of Common Palm Civet in the old-aged oil palm plantations due to abundant feed sources, it is supported by the discovery of Rodentia animals (rats and squirrel) as many as 11 individuals. The number of individuals Rodentia animals is the largest number of individuals compared with all land cover, so it becomes one of the emergences of Common Palm Civet. Species Common Palm Civet has a role as a predator of small animals such as rats and squirrels [30]. In addition, with the presence of Civet Mongoons can give advantages to suppress pests such as squirrels and rats as a fruit-eating palm.

The missing mammal species, as well as new mammal species due to changes in land from shrubs and coconut plantation into oil palm plantations in detail, can be seen in Table 4 below.

Table 3. Types of mammal loss and gain due to shrub and coconut plantation changes into palm oil plantations of BPME Estate

\begin{tabular}{|c|l|c|c|}
\hline No. & Type of Change & Loss & Gain \\
\hline 1 & $\begin{array}{l}\text { Before Oil Palm Plantation }- \\
\text { Young-aged Oil Palm }\end{array}$ & $\begin{array}{l}\text { Plantain Squirrel, Malayan } \\
\text { Field Rat and Giant Sunda } \\
\text { Rat }\end{array}$ & 0 \\
\hline 2 & $\begin{array}{l}\text { Before Oil Palm Plantation }- \\
\text { Middle-aged Oil Palm }\end{array}$ & $\begin{array}{c}\text { Leopard Cat and Giant } \\
\text { Sunda Rat }\end{array}$ & Malayan Field Rat \\
\hline 3 & $\begin{array}{l}\text { Before Oil Palm Plantation - } \\
\text { Old-aged Oil Palm }\end{array}$ & $\begin{array}{c}\text { Eurasian Wild Pig and } \\
\text { Giant Sunda Rat }\end{array}$ & $\begin{array}{c}\text { Common Palm Civet and } \\
\text { Malayan Field Rat }\end{array}$ \\
\hline
\end{tabular}

Overall, changes in shrub cover and coconut plantation into oil palm plantations in BPME Estate have removed one (1) mammal species, Giant Sunda Rat and the change of one (1) new mammal species namely Common Palm Civet. Furthermore, when viewed from the number of individuals in each species found, an increase in the number of individuals occurs in 3 species of mammals namely Plantain Squirrel, Malayan Filed Rat and Leopard Cat due to the change. However, the number of individuals in the wild boar species experienced a $60 \%$ decrease in the encounter.

Based on the data in Figure 3, shrubs and coconut plantation into oil palm plantations (accumulation of young-aged oil palm, medium-aged oil palm, and old-aged oil palm) have 
taken certain mammals. The types of missing mammals occur in young-aged oil palm areas, where there are two species of mammals: Plantain Squirrel and Giant Sunda Rat are not found in the young-aged oil palm area. However, shrubs and coconut plantation into old-aged oil palm have bought a new type of Common Palm Civet dan Malayan Field Rat. Furthermore, from the results of mammalian observations showed that found one type of protected mammals based on Government Regulation No. 7 of 1999 namely Leopard Cat (Table 4).

Table 4. Status of Species Protection and Scarcity

\begin{tabular}{|c|c|c|c|c|c|c|}
\hline \multirow[t]{2}{*}{ No. } & \multirow[t]{2}{*}{ Species Name } & \multirow[t]{2}{*}{ Scientific Name } & \multirow[t]{2}{*}{ Family } & \multicolumn{3}{|c|}{ Conservation Status } \\
\hline & & & & IUCN & CITES & $\begin{array}{c}\text { PP } \\
7 / 1999\end{array}$ \\
\hline 1 & Leopard Cat & $\begin{array}{l}\text { Prionailurus bengalensis (Kerr } \\
\text { 1792) }\end{array}$ & Felidae & LC & AP I & $\mathrm{P}$ \\
\hline 2 & $\begin{array}{l}\text { Malayan Field } \\
\text { Rat }\end{array}$ & Rattus tiomanicus (Miller 1900) & Muridae & LC & TT & NP \\
\hline 3 & $\begin{array}{l}\text { Giant Sunda } \\
\text { Rat }\end{array}$ & $\begin{array}{l}\text { Sundamys muelleri (Müller } \\
1838 \text { ) }\end{array}$ & Muridae & $\mathrm{LC}$ & TT & $\mathrm{NP}$ \\
\hline 4 & $\begin{array}{l}\text { Plantain } \\
\text { Squirrel }\end{array}$ & $\begin{array}{l}\text { Callosciurus notatus (Boddaert } \\
\text { 1785) }\end{array}$ & Sciuridae & LC & TT & NP \\
\hline 5 & $\begin{array}{l}\text { Eurasian Wild } \\
\text { Pig }\end{array}$ & Sus scrofa (Müller 1838) & Suidae & VU & TT & $\mathrm{NP}$ \\
\hline 6 & $\begin{array}{l}\text { Common } \\
\text { Palm Civet }\end{array}$ & $\begin{array}{l}\text { Paradoxurus hermaphroditus } \\
\text { (Pallas 1777) }\end{array}$ & Viveridae & $\mathrm{LC}$ & AP III & NP \\
\hline
\end{tabular}

Information: PP RI No7/1999; P (Protected); NP (Not Protected); AP (Appendix CITES); VU (Vulnerable); LC (Least Concern); NI (Not Included)

Based on CITES category, Leopard Cat are categorized as Appendix II and Common Palm Civet, including Appendix III category. In the IUCN category, the mammal species found in the oil palm plantation belong to the Vulnerable (VU) category for the wild boar species and the remainder is categorized as Least Concern (LC) (Table 3).

\section{Summary}

1. Overall, the change from shrubs and coconut plantation into oil palm plantations of BPME Estate have increased the number of mammals and no significant change impacts on species diversity.

2. The impact of oil palm plantations leads to differences in the composition of mammal species. The highest species composition difference is found in old oil cover with the lowest species equality of 0.50 , while the lowest composition difference is shown by young-aged oil palm with the highest species equality of 0.67 . Overall, the compilation of land cover prior to oil palm plantations (shrubs and coconut plantation) with oil palm plantations (accumulation of young-aged oil palm, medium-aged oil palm, and old-aged oil palm) has a similar species value of 0.67 .

3. The change from shrubs and coconut plantation into oil palm plantations has eliminated one type of the Giant Sunda Rat with a percentage of 33.33\%. However, these changes also acquire new types such as Malayan Field Rat and Common Palm Civet with a percentage of $66.67 \%$.

\section{References}

1. Bappenas Strategy and Action Plan for Indonesian Biodiversity 2003-2020 [National Document]. (National Development Planning Agency, Jakarta, 2003) 
2. I. Maryanto, M. Noerdjito, T. Partomihardjo, Mount Slamet Ecology: Geology, Climatology, Biodiversity and Social Dynamics. (LIPI Press, Jakarta, 2012)

3. Suhartini, Study Local Wisdom Society in Natural Resource Management and Environment. Proceedings of the National Seminar on Research, Education and Application of Mathematics and Natural Sciences. (Department of Biology Education FMIPA Yogyakarta State University, Yogyakarta, 2009)

4. H. Purba, Menhut Vs Kapolri, Why is unsustainable palm oil expansion a major environmental problem?. Agro Observer. Downloaded from http://palmoilandtheenvironment.blogspot.com, (2007)

5. Y. Syaukat, Creating Economic Competitiveness and Environment of Indonesian Palm Oil Industry. (Agrimedia MB-IPB, Bogor, 2008)

6. T.M. Li, Social impacts of oil palm in Indonesia: A gendered perspective from West Kalimantan. Occasional Paper 124. (CIFOR, Bogor, Indonesia, 2015)

7. N.S. Sodhi, Southeast Asian biodiversity: an impending disaster. Trends Ecol Evol. 19: 654-660 (2004).

8. FAO, Global Forest Resources Assessment 2005. (FAO, Wahington, 2006).

9. N.S. Sodhi, B.W. Brook, Southeast Asian Biodiversity in Crisis. (Cambridge University Press, Cambridge, 2006).

10. W.F. Laurance Forest destruction in tropical Asia. Curr Sci. 93:1544-1550. (2007).

11. M.L. Pant, A. Lehikoinen, L. Uusitato, R. Venesjarvi R, How to value biodiveristy in environmental management? Ecological Indicators 55: 1-11 (2015).

12. A. Muin, Plantation of Oil Palm Plantations with Conservation Insight. [tesis]. (Bogor Agricultural University, Bogor, 2013).

13. L.P. Koh and D.S. Wilcove, Cashing in palm oil for conservation. Natur. 448: 993-994 (2007).

14. J.P.W. Scharlemann and W.F. Laurance, How green are biofuels?. Science. 319: 43-44 (2008).

15. D. Tilman, J. Fargione, B. Wolff, Forecasting agriculturally driven global environmental change. Science. 292: 281-284 (2001).

16. N. Novriyanti, Take control of forest pests [Internet]. [downloaded 2017 Jan 23]. Available on: https://www.researhgate.net/publication/307966325_ kendalikan_hama_hutan. (2016).

17. I.W.S. Anggraeni, Long-tailed monkey population and habitat (Macaca fascicularis) in mangrove ecosystems of Wonorejo and surrounding areas, Surabaya [essay]. Bogor (ID): Bogor Agricultural University (2013).

18. H. Mutiarani, Planning and testing of traps, testing of rodenticidal type in controlling Rattus tiomanicuss mill, Rattus rattus diardii linn, and Rattus argentiventer rob \& klo [essay]. Bogor (ID): Bogor Agricultural University (2009).

19. A. Suyanto, Mammals in Halimun Mountain National Park West Java. Bogor (ID): BCPJICA (2002).

20. A.E. Magurran, Why diversity? In Ecological diversity and its measurement (pp. 1-5). Springer, (1988).

21. C.J. Krebs, A review of the Chitty hypothesis of population regulation. Canadian journal of zoology, 56(12), 2463-2480, (1978).

22. J.C. Welty and L. Baptista, The life of birds, (1988). 
23. H.S. Alikodra, Dasar-dasar pembinaan margasatwa. Fakultas Kehutanan Institut Pertanian Bogor, (1979).

24. R.H. MacArthur and J.W. MacArthur, On bird species diversity. Ecology 42: 594-598 (1961)

25. A.P. Kartono, The diversity and abundance of mammals in PT Sukses Tani Nusasubur Kalimantan Timur plantation. Media Konservasi. 20 (2): 85-92 (2011).

26. Mawazin, A. Subiakto, Diversity and composition of natural regeneration of logged peat swamp forests in Riau. J Forest Rehabilitation. 1(1):59-73 (2013).

27. D.I. Junaedi, The diversity of plant communities in Gunung Ciremai National Park. Buletin Kebun Raya Indonesia. 11(2): 25-32 (2008).

28. G. Davies, J. Payne, A Faunal Survey of Sabah. (WWF-Malaysia, Kuala Lumpur, 1982).

29. Y. Santosa, A. Perdana, The role of high conservation value areas in the conservation of mammal species diversity in oil palm plantations: case studies of Riau Province. Pros Sem Nas Masy Biodiv Indon. 3(1): 81-87 (2016).

30. I. Maryanto, M. Noerdjito, T. Partomihardjo, Mount Slamet Ecology: Geology, Climatology, Biodiversity and Social Dynamics (LIPI Press, Jakarta, 2012).

31.S. Yue, Effect of oil palm plantation mammal communities in northeastern Borneo[Thesis]. (2014) 